\title{
DOI 10.31558/2307-2318.2018.4.19
}

УДК 339.9

Усик I. О., здобувач кафедри менеджменту та поведінкової економіки, Донецький національний університет імені Василя Стуса, м. Вінниця

\section{МЕТОДИЧНІ ПІДХОДИ ОЦІНКИ СТРУКТУРНОЇ ТРАНСФОРМАЦІЇ КРАЇН} СВІТУ І УКРАЇНИ В УМОВАХ ГЛОБАЛІЗАЦЇ̈

У статті обгрунтовано необхідність оцінки структурної трансформації країн світу і України в умовах глобалізації. Запропоновано для оцінки структурної трансформації країни використовувати три підходи: підхід оцінки трансформації за рівнем індексу Бертельсмана; підхід структурних відмінностей в чисельності зайнятих за видами економічної діяльності за індексом Рябцева та підхід оцінки структурної трансформації економіки за видами економічної діяльності. За результатами оцінки трансформації за рівнем індексу Бертельсмана встановили, що за його рівнем країни перехідної економіки розподілилися на європейські та пострадянські країни. Динаміка індексу Бертельсмана для країн з перехідною економікою за 2006-2016 рр. дозволила дійти до висновку щодо їхньої внутрішньої неузгодженості, що підкреслює наявність структурної трансформації. Результати оцінки структурних відмінностей в чисельності зайнятих за видами економічної діяльності дозволили виявити значні структурні відмінності через різні фази «посткондратьєвської» довгої хвилі: економіка 1990-х рр. була у висхідній фазі, а економіка 2017 р. ввійшла в спадну фазу. Результати оцінки структурної трансформаціїі економіки за видами економічної діяльності дозволили виявити значні структурні відмінності за досліджений період. Подальші дослідження будуть спрямовані на обгрунтування моделювання структурної трансформації економіки країни 3 метою прогнозування іiї галузевої структури з врахуванням глобалізаційних викликів.

Ключові слова: структурна трансформація, оцінка, підходи, індекс Бертельсмана, індекс Гатєва, індекс Салаї, індекс Рябцева.

\section{Усик И.А. \\ МЕТОДИЧЕСКИЕ ПОДХОДЫ ОЦЕНКИ СТРУКТУРНОЙ ТРАНСФОРМАЦИИ СТРАН МИРА И УКРАИНЫ В УСЛОВИЯХ ГЛОБАЛИЗАЦИИ}

В статье обоснована необходимость оценки структурной трансформации стран мира и Украины в условиях глобализации. Предложено для оценки структурной трансформации страны использовать три подхода: подход оценки трансформации по уровню индекса Бертельсмана; подход структурных различий в численности занятых по видам экономической деятельности по индексу Рябцева и подход оценки структурной трансформации экономики по видам экономической деятельности. По результатам оценки трансформации по уровню индекса Бертельсмана определили, что по его уровню страны переходной экономики распределились на европейские и постсоветские страны. Динамика индекса Бертельсмана для стран с переходной экономикой в 2006-2016 гг. позволила прийти к выводу об их внутренней несогласованности, что подчеркивает наличие структурной трансформации. Результаты оценки структурных различий в численности занятых по видам экономической деятельности позволили выявить значительные структурные различия из-за различных фаз «посткондратьевськои» длинной волны: экономика 1990-х гг. была в восходящей фазе, а экономика 2017 г. вошла в нисходящую фазу. Результаты оценки структурной трансформациии экономики по видам экономической деятельности позволили выявить значительные структурные различия за исследованный период. Дальнейшие исследования будут направлены на 
обоснование моделирования структурной трансформации экономики страны с целью прогнозирования ее отраслевой структуры с учетом глобализационных вызовов.

Ключевые слова: структурная трансформация, оценка, подходы, индекс Бертельсмана, индекс Гатева, индекс Салаи, индекс Рябцева.

Usyk I. O.

METHODICAL APPROACHES FOR ESTIMATION OF STRUCTURAL TRANSFORMATION OF THE COUNTRIES OF THE WORLD AND UKRAINE IN GLOBALIZATION CONDITIONS

The article substantiates the necessity of an assessment of the structural transformation of the countries of the world and Ukraine in the conditions of globalization. It is proposed to use three approaches to assess the structural transformation of the country: the approach to assess the transformation by the level of the Bertelsmann index; the approach of structural differences in the number of employed by types of economic activity by the Ryabtsev index and the approach to assessing the structural transformation of the economy by type of economic activity. According to the results of the assessment of the transformation by the level of the index Bertelsmann found that, according to his level, the countries of transition economy were divided into European and post-Soviet countries. The dynamics of the Bertelsman Index for countries with economies in transition for 2006-2016 allowed them to conclude that their internal inconsistencies highlighted the existence of a structural transformation. The results of the evaluation of the structural differences in the number of employed by types of economic activity allowed to reveal significant structural differences through the various phases of the «postkonradyev» long wave: the economy of the 1990's was in the ascending phase, and the economy in 2017 entered the downward phase. The results of the assessment of the structural transformation of the economy by types of economic activity allowed to reveal significant structural differences for the investigated period. Further research will be aimed at substantiating the modeling of the structural transformation of the country's economy in order to predict its sectoral structure taking into account globalization challenges.

Key words: structural transformation, estimation, approaches, Bertelsmann index, Gatey's index, Salai index, Ryabtsev index.

Постановка проблеми. Структурні трансформації в економіці країн проявляються у формі зміни положення елементів, пропорцій і кількісних характеристик економічної системи. Змістом структурних трансформацій $є$ зміна пропорцій і зв'язків в структурі економіки, а також основних характеристик економічної системи. У той же час, властивості системи виражаються в певних кількісних показниках: частках, вагах і пропорціях, які характеризують стан елементів в системі.

Аналіз структурного зрізу економічного розвитку України дає змогу розкрити основні макроекономічні диспропорції, притаманні вітчизняній економіці, та показати, що досягнення макроекономічної рівноваги в країні можна лише за умови структурної трансформації.

Аналіз останніх досліджень та публікацій. Структурні трансформації економіки України, шляхи та перспективи ії подальшого розвитку досліджуються вітчизняні науковці О. Амоша, В. Геєць, Ю. Кіндзерський, Л. Федулова й ін. [1-4].

Виділення невирішеної проблеми. Високо оцінюючи значну кількість науково обгрунтованих пропозицій щодо різних підходів до оцінки структурної трансформації економіки країни, вважаємо за потрібне оцінити, наскільки зміни галузевої структури України відповідають загальносвітовим тенденціям, завданням, що стоять перед 
вітчизняної економікою сьогодні та сприятимуть підвищенню іiі конкурентоспроможності на світових ринках.

Метою статті $\epsilon$ виявлення тенденцій структурних трансформацій економіки країн світу та України.

Виклад основного матеріалу. Найбільш часто в економічній літературі зарубіжних країн аналіз структурних трансформацій здійснюється за допомогою різних підходів (рис. 1).

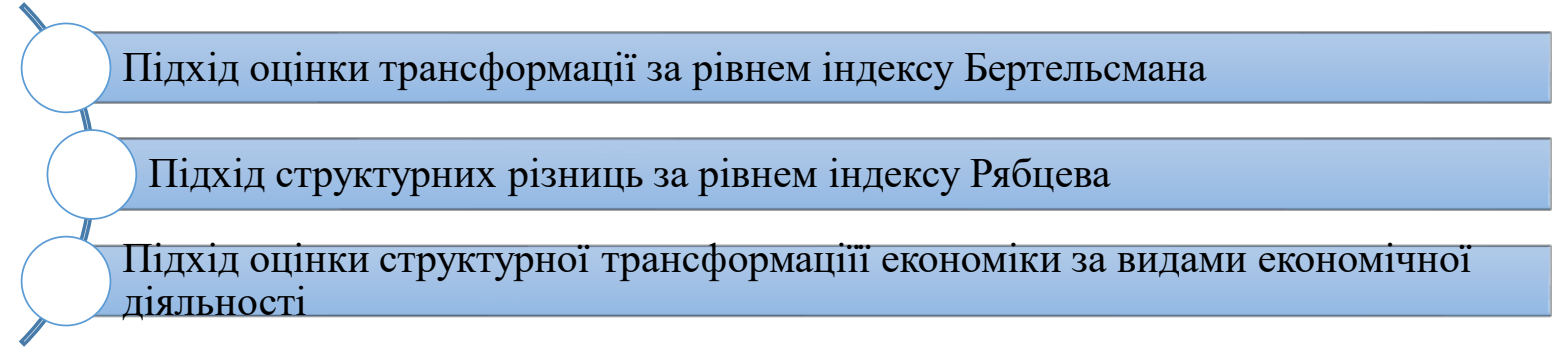

Рис. 1. Підходи до оцінки структурної трансформації

Джерело: побудовано авторами

Здійснимо оцінку структурної трансформації країн світу та України за вказаними підходами.

Підхід оцінки трансформації за рівнем індексу Бертельсмана дозволяє досліджувати трансформацію економік, що $є$ дуже нестійкими і мінливими, який дозволяє вивчити феномени і процеси, які зазвичай приховані звичними інститутами i соціальної структурою, цінностями і масовою підтримкою.

За класифікацією ООН Україна - це країна з перехідною економікою, тому систематизуємо індекс трансформації Бертельсмана за 2006-2016 рр. саме для цього блоку країн (табл. 1).

За результатами оцінки трансформації за рівнем індексу Бертельсмана можна стверджувати, що спостерігається наочно картина щодо розподілу блоку країн 3 перехідною економікою на європейські та пострадянські країни. Взаємозв'язок між субіндексами індексу трансформації Бертельсмана для країн з перехідною економікою в 2016 р. наведені на рис. 2.

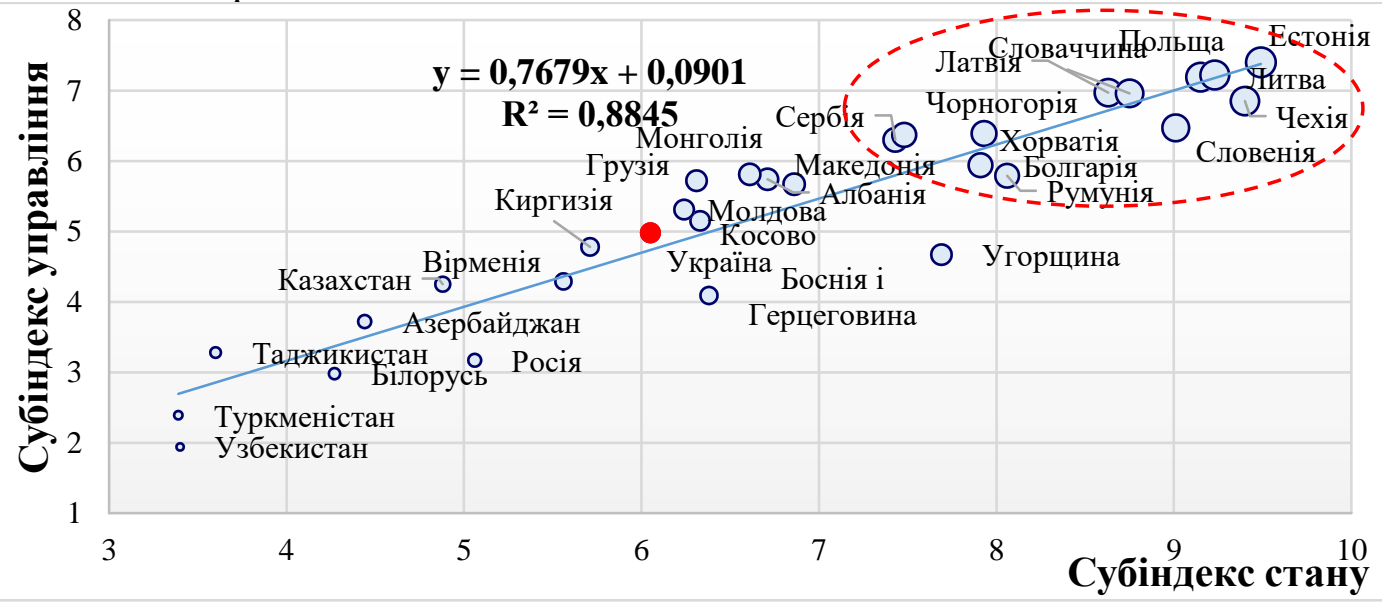

Рис. 2. Взаємозв'язок субіндексів індексу трансформації Бертельсмана для країн 3 перехідною економікою в 2016 р.

Джерело: побудовано автором за даними Unctadstas [5] 


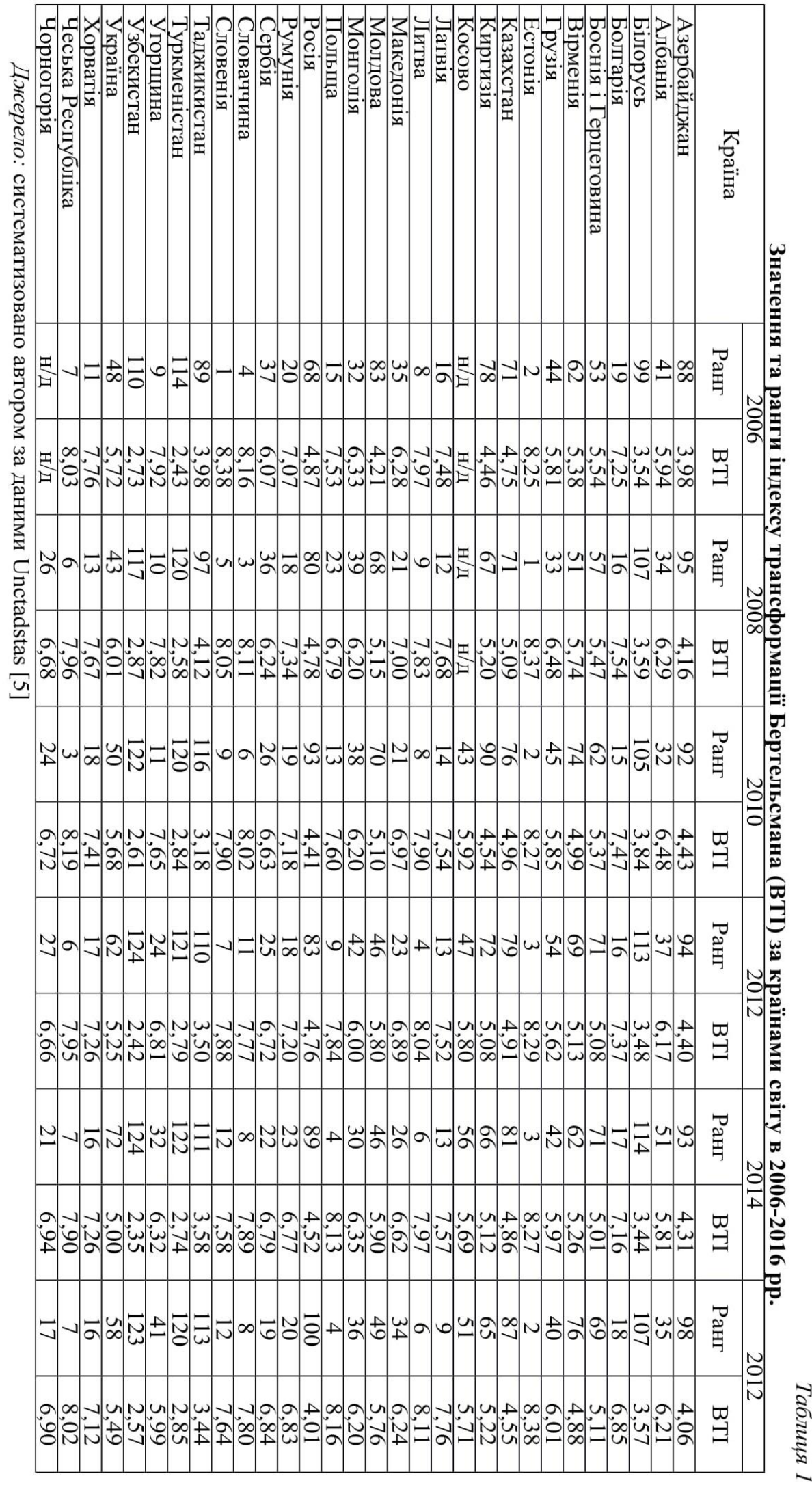


Отже, за динамікою індексу Бертельсмана для країн з перехідною економікою за 2006-2016 pр. можна зробити висновки щодо їхньої внутрішньої неузгодженості: субсистеми суспільства, як відносно автономні цілісності, здатні реагувати на нові виклики особливим способом. Субсистеми освіти, науки, корпоративної економіки, ринків нерухомості, індустрії дозвілля тощо здатні сформувати вектор розвитку, який, разом 3 тим, веде до системної декомпозиції і нестійкості та вимагає «виборчої спорідненості» (в термінології М. Вебера), різнорівневих погоджень 3 іншими субсистемами з метою забезпечення стійкості і цілісності суспільства. Але до того як узгодження стане актуалізованим, саморозвиток може встигнути сформувати досить стійкі, зовні слабо узгоджені, але внутрішньо узгоджені унікальні форми субсистем (інститутів, практик).

Дане положення підкреслює високу вірогідність трансформаційного процесу, яка - всупереч дії загальних регуляторів - при необхідності виробляє розбіжності в спрямованості і результатах трансформації на різних фазах процесу. Такі розбіжності в структурно-економічній динаміці добре помітні на багатьох прикладах пострадянських країн і країн Східної Свропи, які починали цей шлях в кінці 1980-х рр. в подібних умовах.

Україна також до кінця 2016 р. погіршила свої показники за субіндексом стану через погіршення показників стану ринкової економіки, зокрема індекс «Валюта i стабільність цін» зменшився з 8,5 (в 2006 р.) до 5,5 (в 2016 р.).; «Рівень соціальноекономічного розвитку» - 3 6,0 до 5,0; «Економічні показники» - 38 8,0 до 2,0; «Організація ринку і конкуренція» - 3 6,8 до 6,5 тощо.

3 метою підтримки власної стійкості країни не можуть не перейматися проблемою подолання декомпозиції і виникнення в зв'язку з цим бар'єрів розвитку, не можуть не потурбуватися про пошук нових способів досягнення згоди і координованої взаємодії субсистем.

Для оцінки структурних трансформацій розвитку економіки деякі автори запропонували використовувати ще один nidxid, який передбачає дослідження ринкових перетворень ринку праці краӥни [6].

Результати та наслідки трансформації соціально-трудових відносин знайшли своє відображення в зміні зайнятого населення i його структури, які під дією макроекономічних чинників піддаються подальшим спотворенням, що знижує економічну активність і якість життя. В першу чергу, це пов'язано 3 перебудовою зайнятості через зміни структури економіки. Тому є правомірним використання його для аналізу структурної трансформації.

На основі емпіричних даних структури зайнятих в економіці України в розрізі видів економічної діяльності за 1991-2018 рр. встановлено, що провідними видами економічної діяльності, що забезпечують зайнятість населення країни, є торгівля, транспорт, харчування, а також ділові та адміністративні послуги та державне управління, громадські, соціальні та інші послуги і заходи. Так, в 1991 р. їх питома вага в загальній зайнятості складала 26,2% і 24,2 \% відповідно.

Висока питома вага зайнятих приходилася також і на сільське господарство 22,0 \%. В 2018 р. левова частка у структурі зайнятих в Україні припадала на торгівлю, транспорт, харчування, а також ділові та адміністративні послуги. Їхня питома вага збільшилася на 8 \% і склала в 2018 р. 34,2 \%. Збільшення відбулося і відносно державного управління на 2,1 \% і склала 26,3\%. Що стосується сільського господарства, то в 2018 р. його питома вага склала лише $15,3 \%$, тобто зменшилася на $6,7 \%$. 
За досліджуваний період 1991-2018 рр. структура зайнятих за видами економічної діяльності зазнала помітних змін. При цьому за суміжні періоди часу розбіжності в структурі загальної чисельності працездатного населення інтерпретувалися в більшості своїй як «тотожність структур» за видами економічної діяльності, використовувався індекс В. М. Рябцева - інтегральний коефіцієнт структурних відмінностей [7]:

$$
I_{R}=\sqrt{\frac{\sum_{i=1}^{n}\left(d_{2}-d_{1}\right)^{2}}{\sum_{i=1}^{n}\left(d_{2}+d_{1}\right)^{2}}}
$$

де $\mathrm{d}_{1}, \mathrm{i} \mathrm{d}_{2}-$ питомі градації двох структур;

$i=1,2,3, \ldots$,

$n$ - число градацій.

Для порівняльної характеристики структури зайнятих за видами економічної діяльності в країнах з перехідною економікою розрахуємо індекс Рябцева, порівнюючи структуру зайнятості в конкретній країні та країнах з перехідною економікою взагалі в 1991 р. та 2018 р. (табл. 2).

Наявність значних структурних відмінностей в економіці за розглянутий період пояснюється порівнянням структур, що відносяться до різних фаз п'ятої «посткондратьєвської» довгої хвилі: висхідної і низхідної фази. Економіка 2011 р. входить в спадну фазу, економіка 1990-х рр. - у висхідну, що обумовлює наявністю значного рівня структурних відмінностей порівнюваних економічних систем.

Базовим індикатором розвитку економіки країни, що характеризує структурноекономічні пропорції і кількісний результат виробництва товарів і послуг традиційно використовується валовий внутрішній продукт. Структурні зрушення в економіці країн носять системний характер і $\epsilon$ частиною глобального макрозрушення, що визначає перехід від індустріального до постіндустріального суспільства.

Одним 3 підходів оцінки структурної трансформації економіки країни запропоновано використати оцінку структурної трансформації економіки за видами економічної діяльності, який заснований на індексному методі. Головна задача індексного аналізу полягає у визначенні ступеня впливу факторних змін значення усередненого показника і змін структури явища. Вирішується це завдання шляхом побудови системи взаємопов'язаних індексів.

Аналіз структурних змін явища заключається у визначенні узагальнюючих показників структурних зрушень. У розробці системи інтегральних показників велика роль належить роботам вчених-статистиків: К. Гатєва, Л. С. Казинця, В. М. Рябцева, А. Салаї та ін. [9]. До найбільш поширених зведеним показників відносяться наступні:

\section{Інтегральний коефіцієнт К. Гатєва:}

$$
I_{G}=\sqrt{\frac{\sum_{i=1}^{n}\left(d_{2}-d_{1}\right)^{2}}{\sum_{i=1}^{n} d_{2}^{2}+\sum_{i=1}^{n} d_{1}^{2}}}
$$

де $\mathrm{d}_{1} \mathrm{i} \mathrm{d}_{2}-$ питома вага частини сукупності за базовий та звітний період відповідно; Індекс структурних зрушень А. Салаї:

$$
I_{S}=\sqrt{\frac{\sum_{i=1}^{n}\left(\frac{d_{2}-d_{1}}{d_{2}+d_{1}}\right)^{2}}{n}}
$$


Критерій В. М. Рябцева: використовувався при розрахунку структурної трансформації економіки країни за чисельністю зайнятих за видами економічної діяльності.

Коефіцієнт К. Гатєва, індекс А. Салаї і індекс В. М. Рябцева є найбільш точними і зручними інструментами для вирішення поставленої у дослідженні мети. Основна проблема використання індексів 3 соціально-економічної статистики - відсутність інтуїтивного розуміння i, як наслідок, складність вибору між ними. Індекси Рябцева і Гатєва відрізняються тільки знаменником, але відсутність ясної інтерпретації не дозволяє виділити кращий [10, с. 14].

Здійснено апробацію методики розрахунку структурних змін в галузевій структурі України за період 2001-2017 pp. Розрахувавши індекси В.М. Рябцева, К. Гатєва i А. Салаї дозволяє зробити висновок про наявність структурних змін (рис. 3).

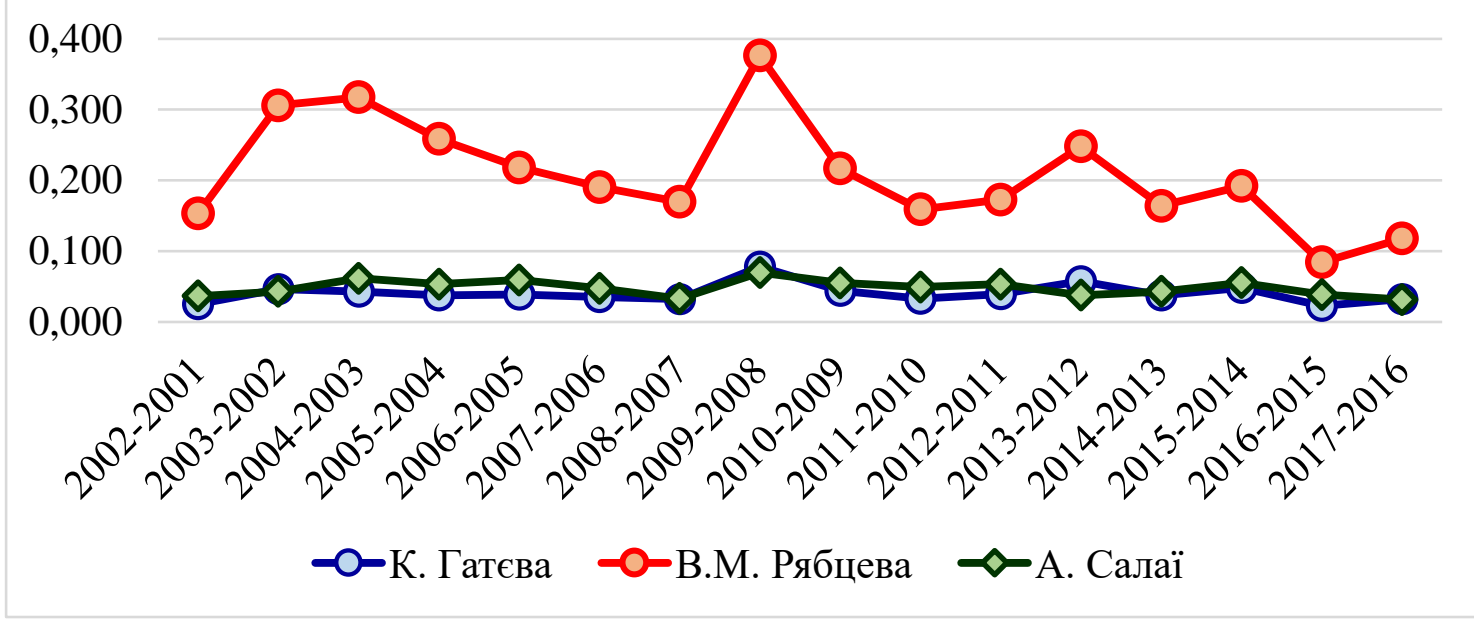

Рис. 3. Графік динаміки структурних змін економіки України за індексами А. Салаї, К. Гатєва та В. М. Рябцева за період 2001-2017 pp.

Джерело: розраховано побудовано автором за даними [11]

Достовірність розрахунків підтверджується виконанням нерівності, виробленої В. М. Рябцевим:

$$
I_{R}<I_{G}<I_{S}
$$

Як випливає з результатів динаміки індексів, представлених на рис. 3, авторські розрахунки вірні.

Отже, узагальнюючи розрахунки структурних зрушень i структурних відмінностей економіки України, отримано наступні результати:

- структура господарських систем областей України в 2017 р. в порівнянні 3 2001 р. змінилася значним чином;

- на підставі розрахунку маси, швидкості і індексу структурних зрушень визначена негативна динаміка в галузях сільського господарства та обробної промисловості;

- за період 1991-2017 рр. структура економіки України характеризується значними структурними відмінностями, обумовленими приналежністю господарських систем до різних фаз економічного циклу, що підтверджує вплив нових ключових чинників розвитку на існуючу систему господарської діяльності. 


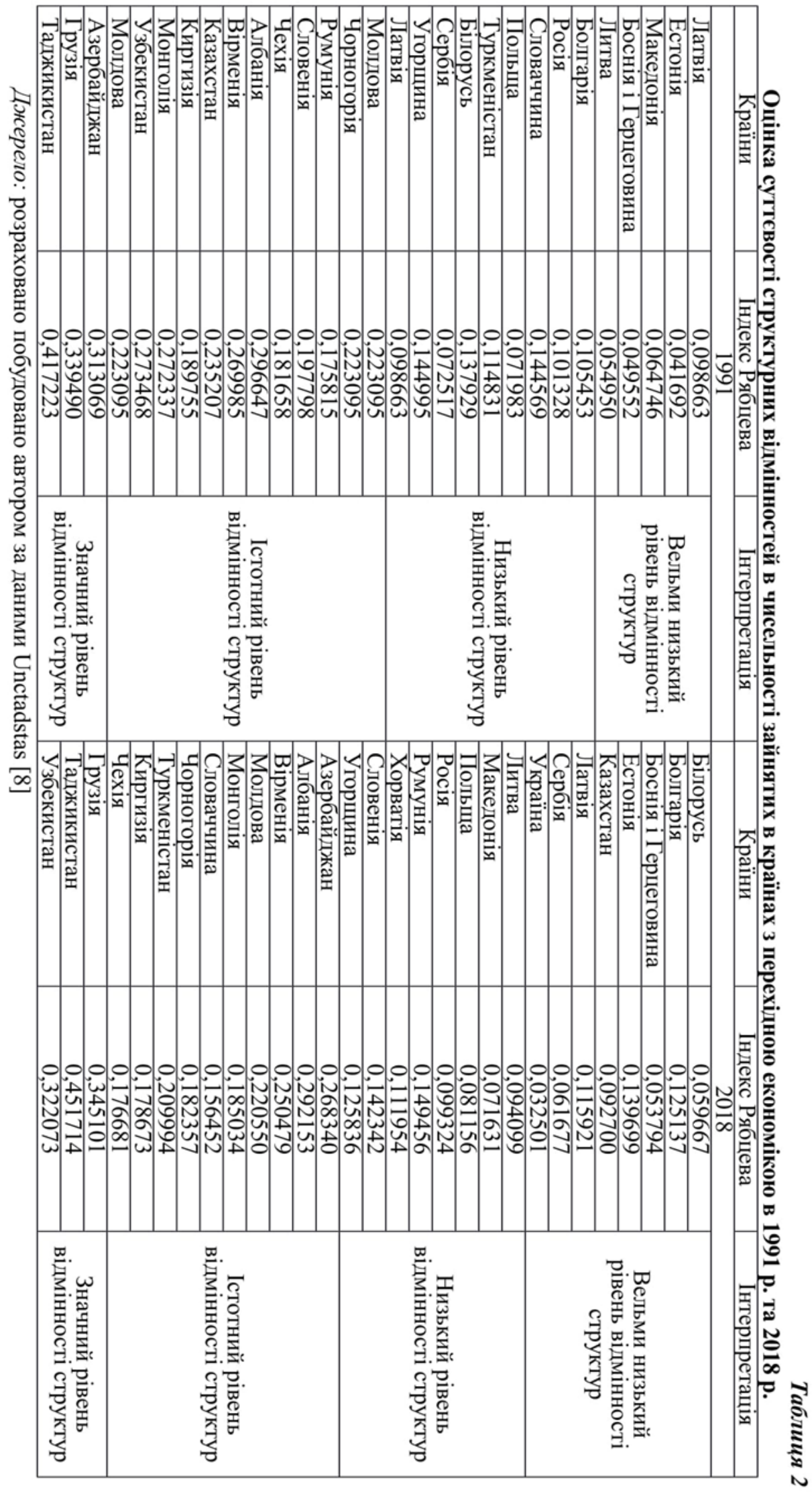


Висновки. Таким чином, для оцінки структурної трансформації країни запропоновано використовувати три підходи: підхід оцінки трансформації за рівнем індексу Бертельсмана; підхід структурних відмінностей в чисельності зайнятих за видами економічної діяльності за індексом Рябцева та підхід оцінки структурної трансформації економіки за видами економічної діяльності, які були апробовані в статті. За результатами оцінки трансформації за рівнем індексу Бертельсмана встановили, що за його рівнем країни перехідної економіки розподілилися на європейські та пострадянські країни. Динаміка індексу Бертельсмана для країн 3 перехідною економікою за 2006-2016 рр. дозволила дійти до висновку щодо їхньої внутрішньої неузгодженості, що підкреслює наявність структурної трансформації. Результати оцінки структурних відмінностей в чисельності зайнятих за видами економічної діяльності дозволили виявити значні структурні відмінності через різні фази «посткондратьєвської» довгої хвилі: економіка 1990-х рр. була у висхідній фазі, а економіка 2017 р. ввійшла в спадну фазу. Результати оцінки структурної трансформаціїі економіки за видами економічної діяльності дозволили виявити значні структурні відмінності за досліджений період.

Перспективи подальших досліджень. Напрямком подальших наукових досліджень авторів стане обгрунтування моделювання структурної трансформації країни з метою прогнозування галузевої структури економіки країни з врахуванням глобалізаційних викликів.

\section{СПИСОК ВИКОРИСТАНИХ ДЖЕРЕЛ}

1. Структурні реформи економіки: світовий досвід, інститути, стратегії для України [О. І. Амоша, С. С. Аптекар, М. Г. Білопольський, С. І. Юрій, Б. М. Андрушків]. Донецьк, 2011. 846 с.

2. Геєць В. М., Шинкарук Л. В., Артьомова Т. І. Структурні зміни та економічний розвиток України. К.: Експрес, 2011. 696 с.

3. Кіндзерський Ю. В. Промисловість України: стратегія і політика структурнотехнологічної модернізації. К., 2013. 536 с. $472 \mathrm{c}$.

4. Федулова Л. І. Технологічна модернізація промисловості України. К., 2008.

5. Сарычева Т.В. Статистическое исследование диспропорций в занятости на муниципальном уровне Республики Марий Эл. URL: https://www.scienceeducation.ru/ru/article/view?id=6865/

6. Індекс Бертельсмана. URL: http://www.bertelsmann-transformation-index.de

7. Бреднева Л.Б. Исследование структуры и структурных различий в экономике Хабаровского края // Вестник ХГАЭП. - 2011. - № 1 (52). - С. 4-10.

8. Офіційний сайт Unctadstas. URL: https://unctadstat.unctad.org

9. Садовничий В.А., Акаев А.А., Коротаев А.В., Малков С.Ю. Моделирование и прогнозирование мировой динамики. М.: ИСПИ РАН, 2012.

10. Статистика: учебник / под ред. А.Е. Суринова. М.: РАГС, 2005. 656 с.

11. Офіційний сайт Державної служби статистики України. URL: http://www.ukrstat.gov.ua 